\title{
POTENTIAL LIMITATIONS FOR POTATO YIELDS IN RAISED SOIL FIELD SYSTEMS NEAR LAKE TITICACA
}

\author{
Diego Sánchez de Lozada ${ }^{1,2}$; Philippe Baveye ${ }^{1 *}$; Robert F. Lucey ${ }^{1,3}$; Ricardo Mamani ${ }^{4}$;Walter \\ Fernandez ${ }^{4}$ \\ ${ }^{l}$ Department of Crop and Soil Sciences, Bradfield Hall, Cornell University, Ithaca, NY - 14853-1901 - USA. \\ ${ }^{2}$ Vicerrectorado Académico Nacional, Universidad Católica Boliviana "San Pablo”, La Paz - Bolivia. \\ ${ }_{4}^{3}$ In memoriam. \\ ${ }^{4}$ Centro de Desarrollo y Fomento a la Autoayuda (CEDEFOA), La Paz - Bolivia. \\ *Corresponding author $<$ philippe.baveye@cornell.edu $>$
}

\begin{abstract}
During the last two decades, various non-governmental organizations have strongly encouraged Bolivian farmers in the Altiplano region near Lake Titicaca to resume the ancestral agricultural practice of constructing raised fields. In addition to improved drainage and possibilities this practice affords for sub-irrigation, advocated benefits of this system traditionally include frost mitigation and high crop yields. Until recently, reliable data to assess the extent of these benefits were unfortunately lacking. In this context, field experiments on raised fields were designed and carried out at two locations in the Bolivian Altiplano to obtain reliable potato yield and temperature data. Observed yields ranged from 2.73 to $10.80 \mathrm{tha}^{-1}$ at the first site, where salinity caused significant yield variability $\left(R^{2}=0.79\right)$. At the second site, yields per raised platform varied between 8.25 and $33.45 \mathrm{tha}^{-1}$. However, comparable yields were obtained in flat control plots in spite of a mid-season frost, and the minimum temperatures differed only by $1^{\circ} \mathrm{C}$ in the conventional plots relative to the raised fields. These results suggest that, under the experimental conditions, the potential benefits of raised fields in terms of frost mitigation or increased yields might only be observable in exceptionally bad years, when extreme frosts wipe out entire potato crops on conventional fields. Nevertheless, it is argued that in spite of these marginally supportive observations, raised-field agriculture may still be a viable option for farmers to consider if the water-filled channels between the raised fields are managed for fish and fertilizer production.
\end{abstract}

Key words: raised fields, productivity, frost mitigation, crop

\section{LIMITAÇÕES POTENCIAIS PARA PRODUTIVIDADE DA BATATA EM SOLOS DE CAMPOS ELEVADOS NO LAGO TITICACA}

RESUMO: Nas últimas duas décadas várias organizações não governamentais entusiasmaram lavradores bolivianos da região do Altiplano, próximo ao Lago Titicaca, a reassumir a prática ancestral de construir campos elevados. Além de sua drenagem melhorada e das possibilidades de implementar a sub-irrigação, as vantagens desse sistema tradicional incluem a mitigação da geada e altas produtividades. Até recentemente não havia dados para avaliar estes benefícios. Neste contexto, experimentos realizados em campos elevados foram planejados e executados em dois locais dentro do Altiplano boliviano, para obter dados confiáveis em relação à produtividade da batata e das temperaturas reinantes. As produtividades observadas variaram de 2,73 a $10,80 \mathrm{t} \mathrm{ha}^{-1}$ no primeiro local, no qual a salinidade provocou uma variabilidade significante na produtividade $\left(\mathrm{R}^{2}=0,79\right)$. No segundo local, as produtividades nas plataformas elevadas variaram de 8,25 a $33,45 \mathrm{t} \mathrm{ha}^{-1}$. Entretanto, produtividades comparáveis foram obtidas nas áreas controle, mesmo na presença de uma geada no meio da estação e de uma diferença de apenas $1^{\circ} \mathrm{C}$ entre as parcelas convencionais e as elevadas. Estes resultados sugerem que nas condições dos experimentos, os benefícios dos cultivos elevados, em termos de mitigação de geada ou produtividade aumentada, poderão apenas ser observados em anos excepcionalmente ruins, quando geadas fortes extirpam a totalidade da plantas dos cultivos convencionais. Entretanto, pode-se argumentar que mesmo com estas observações marginais de apoio, a agricultura em campos elevados poderia ser uma opção viável para agricultores se nos canais repletos de água entre os campos elevados fosse adotada a piscicultura e produção de fertilizantes.

Palavras-chave: campos elevados, produtividade, mitigação de geada, cultura 


\section{INTRODUCTION}

Ancestral agricultural practices of land reclamation and soil and water management have until recently been considered to be mostly of archaeological and historical interest. However, due to difficulties routinely experienced during the technological transfer of modern forms of intensive agriculture to subsistence farmers in developing countries, ancient techniques are nowadays increasingly viewed as possible alternatives to improve agricultural productivity. Raised field agriculture, once widespread on most continents (Denevan \& Turner, 1974), is one of the ancestral practices that have experienced a dramatic resurgence of interest in the last two decades (e.g., Lennon, 1982; Sanchez de Lozada et al., 1998; Stache, 2000).

In the last two decades, prospects of high potato (Solanum tuberosum) yields in raised fields ("suka kollus" in aymara) have been used to encourage farmers in the Bolivian altiplano, near lake Titicaca, to adopt this technology (Kolata, 1991; Daltroy, 1997; Mundy et al., 1999; Lhomme \& Vacher, 2002; Hijmans et al., 2003; Janusek, 2004). However, up to about ten years ago, it was not clear what aspect of this practice had most influence on potato yields, and therefore success could not be guaranteed to farmers before they embarked in the labor-intensive construction of raised fields. In particular, there was little reliable information on the extent to which raised fields might address limitations to agricultural production in the Lake Titicaca region, where the frequency and intensity of mid-season frosts is highly variable (Sanchez de Lozada et al., 1998), water stress situations are common, and soil salinity and low fertility status often severely hamper potato cultivation. In this context, the primary objective of the present study was to observe several factors such as temperature, moisture and soil conditions that are likely to limit potato yields in suka kollus of the Lake Titicaca region.

\section{MATERIAL AND METHODS}

\section{Location of experimental field sites}

The two experimental raised field systems are located near Lake Titicaca, in the Bolivian Altiplano, at elevations around 3820 meters above sea level. A system of suka kollus was built over a period of five months, from September to early January, in Chucara, on the edge of a plain (Pampa Kohani) in the province of Los Andes, in the Department of La Paz (Figure 1). The second experimental raised field system was constructed on a flood plain, approximately 200 meters from a river, in the vicinity of Achacachi, a town in the Omasuyos province of the Department of La Paz

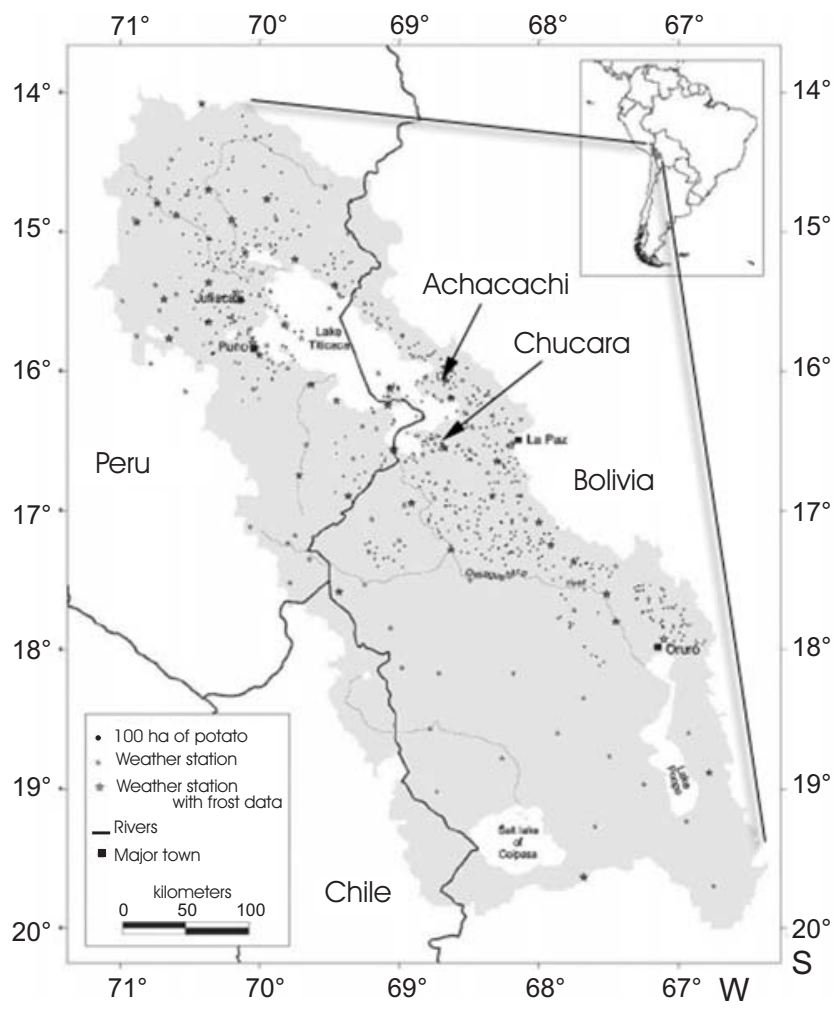

Figure 1 - Map of the Lake Titicaca region (modified from Hijmans et al., 2003), showing areas of potato production, the location of weather stations, and the two field sites, at Chucara and Achacachi.

(Figure 1). Annual precipitations in Chucara and Achacachi are close to $700 \mathrm{~mm}$ and below $600 \mathrm{~mm}$, respectively (Roche et al., 1991). Average yearly temperatures are approximately $8^{\circ} \mathrm{C}$ in both regions. The experimental plots were built on fairly flat terrain with slopes below $1 \%$.

Remains of ancient suka kollus were visible in the form of a wavy micro relief in the region chosen for the experimental field of Chucara. The texture down to the Bt horizon (top $0.4 \mathrm{~m}$ ) ranged between those of a clay and a clay loam soil. The land seemed to have been used only for pasture since the abandonment of the ancient fields. The vegetation consisted of short grasses known locally as chiji, apparently Muhlenbergia fastigiata and Distichlis humilis (A. Van Wambeke, personal communication). A few raised fields had been re-constructed in nearby areas within the last two to five years. Salt patches could be observed in some low-lying parts of the plain near the field site. The soil of the field in Achacachi was a silt loam, and remained fairly uniform down to depths of more than 0.5 meters, where the sand content began to increase. The area had been cropped during the last four years and crop residues sparsely covered the soil surface. 


\section{Construction of the experimental fields}

The design of experiments on newly-established raised fields faces a unique set of constraints as compared to traditional field studies. Because heavy machinery would cause significant soil compaction, the construction of suka kollus has to be performed through human labor and requires inordinate numbers of man-hours of back-breaking work. In part because the technology is ancestral, local farmer communities have proven willing to commit themselves to the needed work. Nevertheless, the area of raised fields that can be (re) constructed in any given year is necessarily limited because farmers only have limited time to devote to the endeavor. Hiring laborers from elsewhere would have enabled the reconstruction of larger acreages of raised fields. Even if it had been financially feasible, this option would have reduced the participatory nature of the experiments. Besides work-related constraints, experiments involving raised fields have additional, unique requirements. Buffer zones are needed between adjacent suka kollu types, to ensure that the effect of, e.g., suka kollu width or canal depth, are properly compared. As a result of these different considerations, a full factorial design was not possible in the experiments, which was conceived instead from the start as a demonstration project for extension purposes, with the recognition that its outcome would have to be corroborated in a higher-budget study, but would nevertheless be of value to suggest what aspect of the suka kollu technology should be emphasized in efforts to stimulate adoption by local farmers.

The layout of the suka kollus in the field was marked with strings and by carving lines with picks. The locations of the future platforms were plowed by hand. This was followed by cutting blocks of sod from the areas where canals would be dug. These blocks were then placed on the edges of the future platforms to retain the new top soil. The next step was the digging of canals and mounding of soil into platforms. Small dikes were left in the canals for purposes of water level control and to reduce the movement of water caused by the wind. Thereafter, the crop bed was prepared by breaking large clods and loosening the soil.

Suka kollus of different cross-sectional dimensions were evaluated at the Chucara and Achacachi sites. Each type of suka kollu consisted of an unreplicated block of five identical platforms separated by canals. The platforms and canals of suka kollus of type I (standard design, which most closely resembled the current recommendations of promoters of suka kollus) were 4 and $2 \mathrm{~m}$ wide, respectively. The height from the bottom of the canals to the surface of the platforms was approximately $0.90 \mathrm{~m}$ for the standard suka kollus in Chucara. The water level was controlled at close to $0.5 \mathrm{~m}$ depth, resulting in a distance of 0.40 $\mathrm{m}$ from the water surface to the top of the platforms. Suka kollus of type I in Achacachi were $0.85 \mathrm{~m}$ high, and the water depths were regulated at $0.45 \mathrm{~m}$. Relative to those of type I, suka kollus of type II have lower water depth in the canals (approximately 0.25 $\mathrm{m}$ ), those of type III have shallower canals (approximately $0.60 \mathrm{~m}$ deep), those of type IV have wider canals $(4.0 \mathrm{~m})$, those of type $\mathrm{V}$ have wider $(6.0 \mathrm{~m})$ platforms, and finally, those of type VI have narrower (1.0 $\mathrm{m})$ canals. The platforms were 50 and 40 meters long in the fields of Chucara and Achacachi, respectively. The experimental fields had control plots with unmodified surface topography (other than plowing), and areas about equal to that of a set of five suka kollus. Suka kollus of type IV were not constructed in Achacachi because the area available was not large enough. Platforms occupied 6,500 and $4,400 \mathrm{~m}^{2}$ in suka kollus fields of Chucara and Achacachi, respectively, whereas the corresponding canal areas were 4,232 , and 2,232 $\mathrm{m}^{2}$. The control plots covered 2,550 and $1,633 \mathrm{~m}^{2}$ in Chucara and Achacachi, respectively.

\section{Soil analysis}

Seven soil samples taken before planting along one platform of each type, to a depth of approximately $0.3 \mathrm{~m}$ with a $0.09 \mathrm{~m}$ diameter auger, were mixed and about $1 / 4$ of the mass was kept as a composite sample. A similar sampling procedure was used on the control plots. In addition to routine soil analyses, total organic carbon and nitrogen were determined by mass spectroscopy. Soil samples from Chucara were pretreated with hydrochloric acid to extract carbonates prior to the total organic carbon analysis.

\section{Temperature and moisture measurements}

Temperature and moisture measurements were made at the control plot, suka kollus of type I, and only one other suka kollu type simultaneously. As a consequence, suka kollus of types II, III, IV, V, and VI were monitored separately from each other for approximately two to four week periods in the order V, IV, III, II, corresponding successively to four comparison periods for the Chucara field (C1 to $\mathrm{C} 4)$, and II, III, VI, V, V for five comparison periods in the Achacachi site (A1 to A5). Plants were harvested for the fifth comparison period in Achacachi (A5). Soil temperature measurements were made at one location in the middle of the control plots and at three locations between the edge and center across the central platforms of each type at depths of $0.05,0.1,0.2$, and $0.3 \mathrm{~m}$. Air temperatures at $0.5 \mathrm{~m}$ above soil surface were also obtained in the middle of the central plat- 
forms and the center of the control plot. Temperatures were recorded every half hour with thermistors multiplexed to Campbell Scientific CR10 data loggers. Soil moisture tensions and depths to the free water table were obtained twice a week at the same locations as the air temperatures. Tensiometers were installed at $0.25 \mathrm{~m}$ depths from the surface.

\section{Crop development}

The plot in Chucara was planted on December 6th with certified seed of a Solanum tuberosum ssp. andigena cultivar, known locally by the name of Ccompis or Paco Imilla. Due to the scarcity of certified seed, another Solanum tuberosum cultivar, known locally by the name of Huaycha Paceña, was used for planting at Achacachi on October 31. All platforms in Achacachi had 49 rows of plants, with a spacing of $0.8 \mathrm{~m}$. Plants were $0.4 \mathrm{~m}$ apart within rows.

The duration of sprout development, vegetative growth, and flowering stages were approximately determined for each platform and the control plot of the Achacachi site. The time between planting and the emergence of approximately $90-95 \%$ of plants was taken as the duration of the sprout development stage. The vegetative growth stage was considered to last from emergence until the time at which flowers began to appear. The duration of flowering was estimated as the time from the end of the vegetative growth stage until all flowers disappeared in a given platform. The averages of the duration of a given stage, and of heights at 15-day intervals were computed for each suka kollu type and the control plot. The samples for plant height consisted of ten randomly selected plants per platform and control plot.

\section{Crop yields}

The entire production of the experimental fields was weighed, carefully keeping track of the location of origin of the harvested potatoes. In order to establish the variability of yields on suka kollus as influenced by the distance to the canals, the widths of two platforms of each type in Achacachi were divided into five segments. Therefore, a given platform consisted of two segments along the edges, two segments midway between the center and the edges, and one central segment. The yield for each segment was determined, after correcting for missing plants, by assuming that each plant occupied a rectangle of $0.4 \mathrm{~m} \times 0.8 \mathrm{~m}$. This procedure was also followed in three regions (Northern, Central and Southern regions) of the control plot, each with the same shape, orientation and area as a platform of type I. The distribution of yields as fresh weight basis was obtained for segments, platforms, suka kollu type, and the control plot.

\section{RESULTS}

\section{Yields in suka kollus and in the control plots}

As yields can be calculated by taking different areas into account, a clarification of the present usage is necessary. The nominal yields take only the planted area into account and reflect growing conditions, whereas the effective yields include the area lost to the canals. Effective yields for a given suka kollus type can be estimated by dividing the nominal yield by the product $(\mathrm{AxB})$, where $\mathrm{A}$ is the sum of areas of a platform plus its adjacent canal divided by the area of the platform of the given type, and B is a correction for areas of distribution canals (1.08 and 1.05 for Chucara and Achacachi, respectively), excluding the main inlet and drainage canals. This distinction between nominal and effective yields was usually not clear in earlier reports on the productivity of suka kollus.

Higher nominal yields were obtained in the suka kollus (S.K.) than in the control plots (T) in Chucara and Achacachi (Table 2). However, the control plot of Chucara was located in the site with the highest salinity. The yield of the control plot for a well-drained region having an area of $200 \mathrm{~m}^{2}$ is presented as the maximum. The relative difference between this maximum at $\mathrm{T}\left(9.45 \mathrm{t} \mathrm{ha}^{-1}\right)$ and that obtained in a suka kollus of type VI (14.59 $\left.\mathrm{t} \mathrm{ha}^{-1}\right)$ is smaller as compared to that of the overall yields in the control plot vs. platforms. The minimum nominal yield for $\mathrm{T}$ was obtained excluding the $200 \mathrm{~m}^{2}$ of the well-drained region. The minimum yield in suka kollus was obtained for the platform closest to the control plot (i.e., where salinity was highest). The effective yields of 5.40 and $4.48 \mathrm{t}$ $\mathrm{ha}^{-1}$, respectively, for the suka kollus and the control plot at Chucara, represent a small difference in light of the salinity disadvantages more prevalent in the control plot. Frosts did not affect yields in Chucara because none occurred until late in the growing season.

The overall nominal yields in the suka kollus $\left(29.97 \mathrm{t} \mathrm{ha}^{-1}\right)$ and the control plot $\left(27.45 \mathrm{t} \mathrm{ha}^{-1}\right)$ of Achacachi differed by a small amount (Table 1). The highest nominal yield in the control plot was obtained in a northern strip with an area equal to that of a platform of type I. The highest yield in the field was obtained in a suka kollu of type VI. The lowest nominal yield in Achacachi was obtained in a suka kollus of type II, which was below the yield of the Southern region of the control plot. Yields on suka kollus of type I and II were lowest and comparable to those obtained from the Southern part of the control plot. Aside frost effects that predominantly affected the control plot, soil conditions must account for the differences in yields. 
Table 1 - Potato tuber yields in suka kollus and control plots in Chucara and Achacachi.

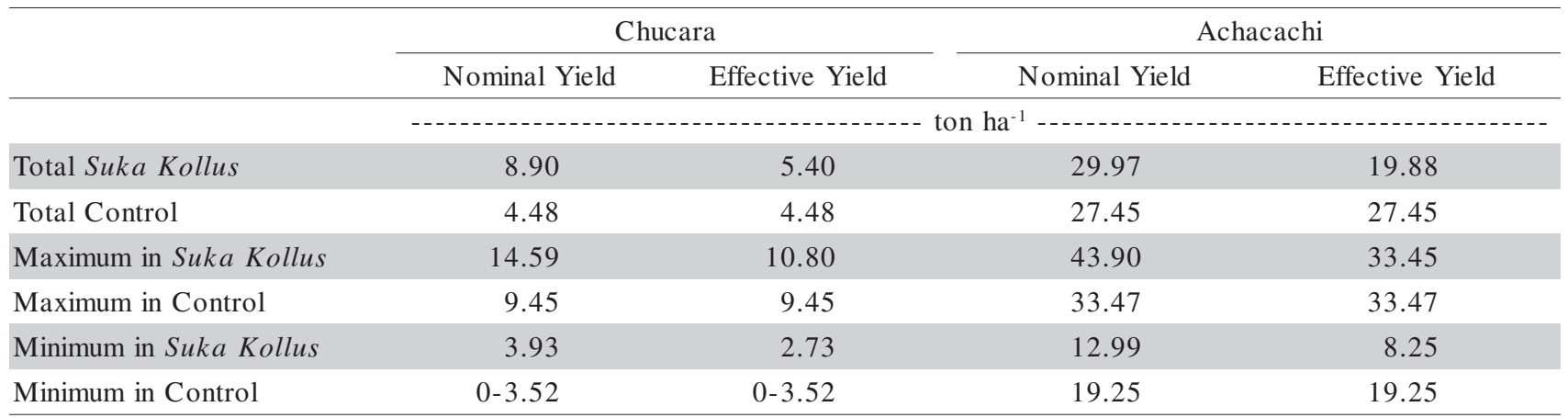

Table 2 - Selected chemical properties of composite soil samples taken in suka kollus 4 of each type and in different regions of the control plot in Achacachi.

\begin{tabular}{|c|c|c|c|c|}
\hline Suka kollus Type & $\mathrm{C}$ & $\mathrm{N}$ & $\mathrm{P}$ & $\mathrm{K}$ \\
\hline & \multicolumn{2}{|c|}{$-\ldots-0 \%---$} & \multicolumn{2}{|c|}{---- $\mathrm{g} \mathrm{Mg}^{-1}$} \\
\hline I & 1.10 & 0.15 & 0.6 & 48 \\
\hline II & 1.47 & 0.19 & 1.2 & 73 \\
\hline III & 1.79 & 0.23 & 2.2 & 81 \\
\hline $\mathrm{V}$ & 1.85 & 0.23 & 1.5 & 53 \\
\hline VI & 2.05 & 0.25 & 2.4 & 94 \\
\hline TS & 2.00 & 0.24 & 1.3 & 70 \\
\hline $\mathrm{TC}$ & 2.50 & 0.29 & 2.2 & 67 \\
\hline $\mathrm{TN}$ & 2.29 & 0.27 & 2.4 & 53 \\
\hline
\end{tabular}

In terms of effective yields, i.e., after correcting the nominal yields to account for the area lost to canals, the control plot $\left(27.45 \mathrm{t} \mathrm{ha}^{-1}\right)$ showed better results than the suka kollus $\left(19.88 \mathrm{t} \mathrm{ha}^{-1}\right)$.

\section{Distribution of soil conditions}

Salinity was a dominant factor affecting the soils at Chucara. The $\mathrm{pH}$ of most horizons was above 8 ( $1: 1$ by volume soil $\mathrm{H}_{2} \mathrm{O}$ mixture). All horizons bellow $0.15 \mathrm{~m}$ had electrical conductivities above $4 \mathrm{mS}$ $\mathrm{cm}^{-1}$ and an exchangeable sodium percentage ranging between 14 and 77, thus falling into the saline sodic category of the USDA classification of salt affected soils.

The variability in soil properties in the control plot is represented by the results of composite samples taken in its Northern (TN), Central (TC), and Southern regions (TS) (Table 2). The higher carbon and nitrogen contents for types VI, V and III corresponded to suka kollus located in the lowest regions. The original surface sloped downwards from the Southeast to the Northwest. Therefore, suka kollus of types I and II were located in the highest regions, were dryer, and had lower carbon and nitrogen contents. Relatively high levels of carbon and nitrogen were obtained for the control plot due to its low position with respect to suka kollus of type I, and in part because the soils were not mixed with deeper horizons. The low levels of available phosphorous suggested that this element might be growth limiting.

In spite of the careful regulation of water levels in the canals of the suka kollus, the slope of approximately $0.3 \%$ in the field of Achacachi determined the variation of the distance from the soil surface to the free water table at different locations. Average soil water tensions per comparison period ranged from 3 to $18 \mathrm{KPa} \mathrm{Bar}$ in the control plot and from 8 to 49 $\mathrm{KPa}$ Bar in suka kollus. The average soil water tension was lowest in the control plot (T), most likely because the surface had not been raised. The soils in type III were almost as wet as in the control plot but significantly different at an $\alpha$ level of 0.02 . The moisture conditions in the platform of type I were not different from type II, which had the driest conditions. Suka kollus of type V and VI had somewhat lower tensions. Soil moisture might have been a limiting factor in the dryer suka kollus, particularly in types I and II.

Estimates of soil temperatures were obtained by averaging the measurements at four depths between 0.05 and $0.3 \mathrm{~m}$ for each comparison period. The differences in temperature among suka kollus and the control plot (in the order of $1^{\circ} \mathrm{C}$ ) were evaluated through paired t-tests of simultaneous measurements. The temperature differences in a given comparison period were significant at an $\alpha$ level of 0.01 in most cases. The other differences, between suka kollus of types I and VI in A3, as well as between I and T in A5, were significant at an $\alpha$ level of 0.05 . Initially, the soils of suka kollus of type I were warmer than the control plot. The soils became somewhat warmer in the control plot relative to the suka kollu of type I in comparison periods A3 and A4 when the plant canopy became denser in the suka kollus. Soil temperatures remained highest in the platform of type I, followed by type II and the control plot, while the canopy den- 
sity was low. Soil temperatures seemed to be affected mainly by soil moisture and canopy density. The lowest yields were obtained in the warmest platforms.

\section{Differences in minimum air temperatures}

The suka kollus of type I was significantly warmer $(\alpha=0.01)$ than the control plot in all comparison periods (Table 3 ), as concluded from paired t-tests, reaching an average of differences in minimum temperature of $1.1^{\circ} \mathrm{C}$ in comparison period $\mathrm{A} 3$. The canopy seems to have interfered with measurements in comparison period A4. The differences in minimum temperature were significant at an $\alpha$ level of 0.05 or less for suka kollus of type I relative to II and VI. The minimum temperatures were similar in suka kollus of type I and V.

The last early season frost occurred 29 days after planting at the beginning of comparison period A1. Temperatures remained above freezing until late in comparison period $\mathrm{A} 3$, when minimum temperatures fell to $-0.1^{\circ} \mathrm{C}$ in the control plot on days 100 and 101 after planting. Temperatures reached $-1.4^{\circ} \mathrm{C}$ in the control plot on day 105 (February 13), but remained about $1.0^{\circ} \mathrm{C}$ warmer in the suka kollus. Although the frost did not kill any plants, more than half of them in the control plot had necrotic leaves some days later. A few slightly affected plants were spotted in suka kollus

Table 3 - Minimum air temperature averages of the coldest days at $0.5 \mathrm{~m}$ above the surface of the suka kollus and of the control plot for different comparison periods in Achacachi.

\begin{tabular}{lccc}
\hline Ai-I-J-T & Temp. I & Temp. J & Temp. T \\
\hline A1-I-II-T & 1.4 & 1.6 & 0.9 \\
A2-I-III- T & 3.6 & 3.8 & 3.1 \\
A3-I-VI-T & 1.9 & 1.5 & 0.8 \\
A4-I-V-T & 2.7 & 2.6 & 0.9 \\
A5-I-V-T & 1.3 & 1.2 & 0.7 \\
\hline
\end{tabular}

of type V and VI, but no signs of damaged leaves were observed in the other suka kollus. No further frost effects were noticed thereafter.

In order to try to understand which factors contributed to the observed yields in each situation, it is useful to rank qualitatively the suka kollus and the control plot with respect to nitrogen and phosphorous contents, soil moisture, soil temperature and minimum air temperature (Table 4). The ranking by decreasing soil moisture combines knowledge of the soil surface water tensions and the distances to the water table. The minimum air temperatures give an idea of the relative susceptibility to frosts.

\section{Crop development in relation to growth conditions}

Plant emergence occurred first in suka kollus of type VI, followed by the control plot, and then by type V (Figure 2). Emergence took place significantly later $(\alpha=0.01)$ in suka kollus I, II and III. The ranking according to total nitrogen resembles the order of emergence, but some effect might be attributable to soil moisture. The duration of the vegetative growth was similar throughout the field (Figure 2) but seems to have lasted slightly longer for suka kollus of type VI. The initiation of flowering took place statistically
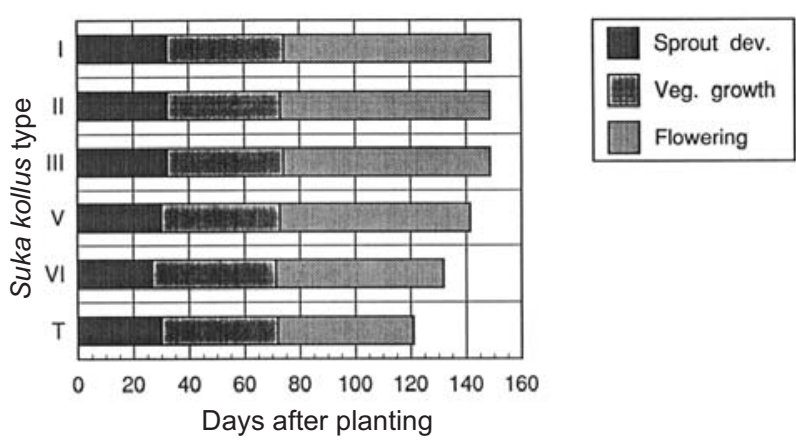

Figure 2 - Average durations of sprout development, vegetative growth, and flowering stages of the potato crop in the different raised fields suka kollus and in the control plot at Achacachi.

Table 4 - Summary of the numerical ranking of selected features of the suka kollus types and control plots at Achacachi (in decreasing order). The total nitrogen and available phosphorous contents relate to the $0-0.3 \mathrm{~m}$ surface soil layer.

\begin{tabular}{lcccc}
\hline Total Nitrogen & Available Phosphorus & Soil Moisture & Soil Temperature & Air Temperature \\
\hline TC & TN & T & I & II \\
TN & VI & III & II & III \\
VI & TC & VI & T & I \\
TS & III & V & VI & V \\
V & V & I & III & VI \\
III & TS & II & & T \\
II & II & & & \\
I & I & & & \\
\hline
\end{tabular}


earlier for suka kollus of type VI and for the control plot, followed a few days later by the other types. The average date of flower initiation for suka kollus of type VI was significantly different at an $\alpha$ level of 0.02 from that of type V. Although flowering began slightly later in suka kollus of types I, II and III than in type $\mathrm{V}$, the difference was not significant. The ranking of minimum air temperatures seems to explain qualitatively the earlier flower initiation of suka kollus of type VI and the control plot.

The differences in plant heights before the frost, especially between days 60 and 90 (Figure 3), seem to be related most closely to nutrient availability, in particular that of nitrogen. Specifically, plants in suka kollus of types VI and V were taller than in type III, followed by plants in the control plot, types II and I. The plants of the control plot were significantly taller ( $\alpha=0.1$ ) than of the suka kollus of type II on day 87 after planting. Plant growth rate seemed affected by the frost (day 105), and followed the minimum temperature ranking closest. Growth ceased completely between days 100 and 115 in the control plot (Figure $3)$. Among the suka kollus, the growth rate in type VI was the most affected, followed by V and III. The growth rates began to decline sooner in these cases, some time after day 80 , possibly due to chilling temperatures not reached in other suka kollu types. Although the plants were smaller $(\alpha=0.05)$ in suka kollus of type III before day 100 , they continued to grow and eventually surpassed in height those in suka kollus V and VI. The frost does not seem to have caused an appreciable decrease of growth rates in suka kollus of types I and II.

Despite milder effects of the frost on the suka kollus, yields were comparable to those of the control plot in Achacachi. The yields in the control plot might have been higher had there been no frost, as inferred from the shorter growth period relative to the suka kollus. On the other hand, an earlier or slightly

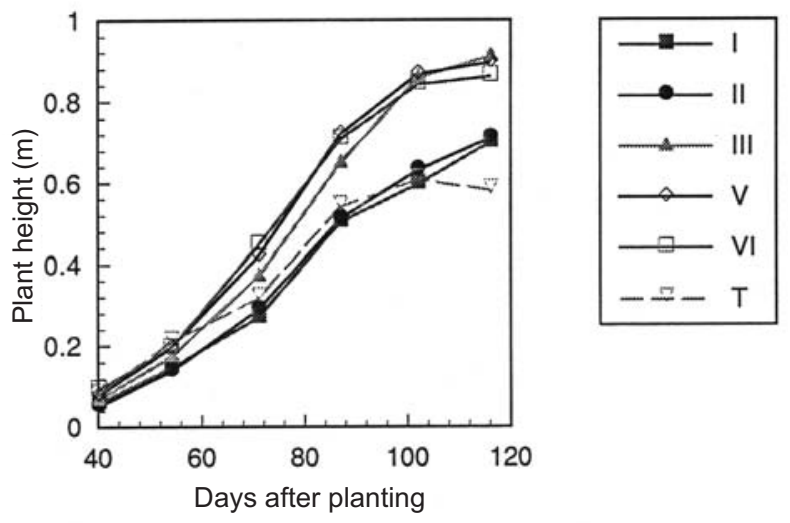

Figure 3 - Average plant height by suka kollus type at different times during the growing season at Achacachi. more intense frost could have led to even lower yields in the control plot and possibly suka kollus of type VI (narrow canals) and V (wide platforms). However, a very intense frost might have affected the crop to similar extents on the entire field, since the observed difference in minimum temperatures between suka kollus and the control plot was only of the order of 1 degree centigrade.

The duration of flowering was clearly shorter for the control plot followed by suka kollus of types VI and V (Figure 2), i.e., in the plots that suffered most from the frost of February 13th. The last flowers in the control plot disappeared about 15 days after the frost. Flowering continued in suka kollus of types VI and $\mathrm{V}$ for an additional 10 and 20 days, respectively. When the plants were cut on day 147 after planting, some flowers remained in suka kollus of type I, II, and III. Most plants of the control plot were turning yellow at this time, while none of the plants of the suka kollus presented signs of senescence. The development of the crop was apparently shortened in the control plot, whereas the effect was less drastic on suka kollus of types VI and V. Flowering ended on average earlier $(\alpha=0.05)$ in suka kollus of type VI than V.

Excluding cold temperature stress, both in Chucara and in Achacachi the variation in nominal yields among suka kollus types seemed closely related to soil chemical and moisture conditions. In the experimental field at Chucara, the yield distribution could largely be accounted for by the spatial variability in soil salinity. A regression of the yields (in $\mathrm{t} \mathrm{ha}^{-1}$ ) of 8 suka kollus and the control plot against salinity values (in mmho $\mathrm{cm}^{-1}$ ) obtained for the corresponding soil composite samples gave a coefficient of determination $\mathrm{R}^{2}$ of 0.790 and the following relationship: Yield $=-3.91$ $x$ Salinity +19.0 ; the electrical conductivity ranged between 1.34 to $4.13 \mathrm{mmho} \mathrm{cm}^{-1}$. The yields in Figure 4 A reflect the effects of salinity. Suka kollus of type I and $\mathrm{V}$, and the control plot, were located in the lowest part of the field, where the poorest yields were obtained. Suka kollus II and IV were in a somewhat higher region and intermediate yields were obtained. The highest yields were obtained on suka kollus III and VI, which were located farthest from the control plot, and on the highest region of the Chucara field where salinity was lowest.

Apparently, yields of the suka kollus of Achacachi were mainly influenced by nutrients and soil moisture. Nominal yields by type most closely reflected the total nitrogen ranking. The highest yields were obtained in suka kollus of types VI, V and III, in that order (Figure 4 B). Although total nitrogen was higher in suka kollus of type II than in I, the yield order is inverted in this case. It is possible that other fac- 

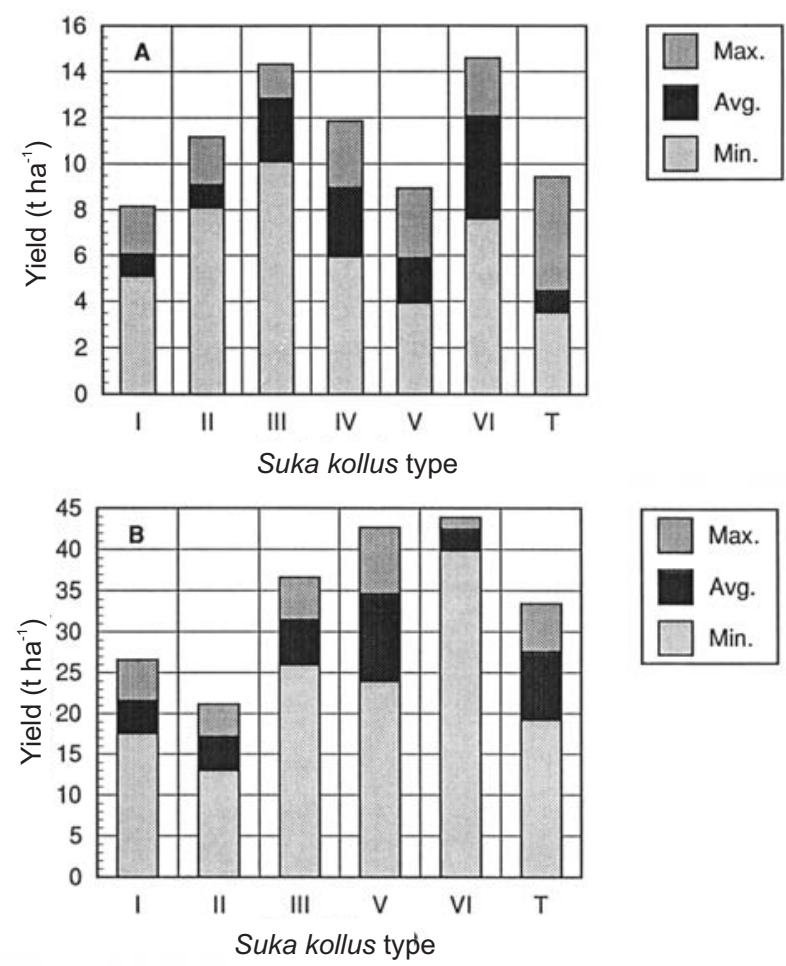

Figure 4 - Nominal yields by suka kollus type at the Chucara (A) and Achacachi (B) sites.

tors offset the difference in nitrogen, such as soil moisture and temperature. The maximum yield for the control plot was obtained in the north central part where nitrogen was high, and the minimum yield was obtained in the southern region where nitrogen and available phosphorous were lower. The higher nominal yields in suka kollus of type III, V, and VI, in spite of somewhat lower nitrogen levels, might be explained by the greater effect of the frost on the control plot. The yield distribution across a platform was apparently not affected by air temperature. However, the highest yields were consistently obtained on segments at the edge of the platforms (Figure 5). If the chemical properties were fairly constant across a platform, then the yield distribution is best explained by soil moisture, which was highest close to the canals.

\section{DISCUSSION}

We need to improve our understanding of how various aspects of the growth environment in raised fields differ from other cropping practices and may translate into higher yields (see, e.g, Sanchez de Lozada et al., 1998). In the raised fields of Achacachi, lower minimum temperatures seemed to lead to a shorter duration of the flowering stage, a decrease in plant growth rate and possibly smaller tuber size. The frost adversely affected plant growth and the duration of the

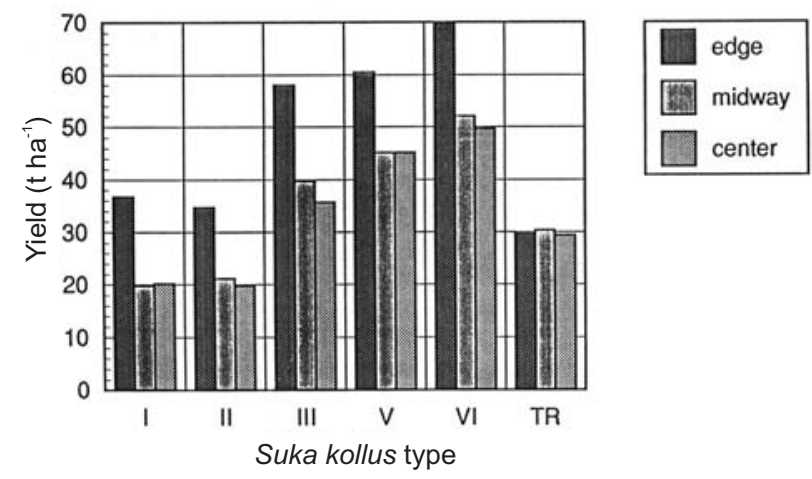

Figure 5 - Hypothetical yields of strips along the center, edge, and midway line of the platforms for the different suka kollus types at the Achacachi site.

flowering stage in the control plot, and to a lesser extent in suka kollus of type VI (with narrow canals) and $\mathrm{V}$ (having wide platforms). Thus, narrow canals (with water) and wide platforms may diminish the mitigation of frosts.

One cannot assume that the use of the ancestral suka kollus technique will always lead to high productivity. The frost mitigation effect observed in suka kollus might lead to a reduction in the risk of crop damage or failure over the long run. However, crop yields would be determined to a large extent by soil properties and water availability. Even if suka kollus are constructed in seasonally flooded flat lands, the fertility and salinity conditions can be quite variable. Because the topsoil of the platforms is better drained than flat areas, the salinity can perhaps be controlled in some cases if water circulation in the canals is sufficient to wash away the salts. For example, acid sulfate soils are cropped in Vietnam by using ditch and bed systems similar to raised fields in order to leach away the acidity (Xuan et al., 1982). For large hectarages of raised fields, this might require a major network of canals draining toward Lake Titicaca (e.g., Ortloff \& Kolata, 1989; Lennon, 1982). Carney et al. (1993) suggested that soil fertility is improved by a higher nutrient and sediment retention in the water of raised field canals as compared to water flow in control sites. However, the dependence of nutrient retention on flow conditions in the canals is not clear, nor to what extent the organic fertilizers translate into improved yields.

Although suka kollus can offer various benefits, their use should be evaluated carefully on a sitespecific basis. The likelihood that raised fields might help relieve land use pressure on hillsides, where currently crop production is concentrated, by reclaiming the poorly drained soils of the flat lands (Denevan, 1970; Erickson \& Candler, 1989; Cañahua et al., 1992) will depend on the various factors that contribute to 
the obtention of high yields. Yields ranged between 2.7 and $33.5 \mathrm{t} \mathrm{ha}^{-1}$ at the two fields evaluated in the present work. Between 1983 and 1986, yields ranging between 8 to 14 tons per hectare were obtained in waru warus ("raised fields" in Quechua) to the Northwest of Lake Titicaca (Erickson \& Candler, 1989) and even lower results were reported more recently by Cañahua et al. (1992). The reintroduction of raised fields in some cases may not necessarily result in more productive agricultural practices as compared to current land use. However, proper account of the factors analyzed in the present work may make it possible to better identify the conditions under which the reintroduction of raised fields is a viable option at specific sites in the Altiplano or in other parts of the world.

Finally, one needs to keep in mind that the present field research took place, out of necessity, in a relatively short period of time (two growing seasons) and looked only at the restricted context of the raised beds, without dealing in parallel with the management of the canals. While this perspective is acceptable from an agronomic research standpoint, it is possible that, had the experiments lasted longer (over several growing seasons), had one systematically attempted to grow nitrogen-fixing algae in the canals and had the farmers year after year spread some of the canal muck over the fields, conclusions reached in terms of potato yields might have been entirely different. Furthermore, if fish farming had been promoted in the canals, as it probably was centuries ago, and if this additional food production were accounted for in the comparison with potato yields in the control plot, it is likely that the raised field technology would fare better, even in years where frost damage is not an issue. An assessment of the benefits of this more complete, less reductionist implementation of raised field agriculture awaits further research.

\section{REFERENCES}

CAÑAhUA, A.; INQUILla, V.; QUISPE, M.; SAlCEDO, C. Produccion de papa amarga y papa dulce en agrosistemas de camellones (waru waru) y pampa. In: PIWA. Avances de investigacion sobre la tecnologia de Waru Waru II. Produccion agricola. La Paz, Bolivia: Convenio PELT/INADE - IC /COTESU, 1992. p.23-38. (Producciones CIMA).

CARNEY, H.J.; BINFORD, M.W.; KOLATA, A.L.; MARIN, R.R.; GOLDMAN, C.R. Nutrient and sediment retention in Andean raised-field agriculture. Nature, v.364, p.131-133, 1993.

DALTROY, T.N. Recent research on the Central Andes. Journal of Archaeological Research, v.5, p.3-73, 1997.
DENEVAN, W.M. Aboriginal drained-field cultivation in the Americas. Science, v.169, p.647-654, 1970.

DENEVAN, W.M.; TURNER, B.L. Forms, functions and associations of raised fields in the old world tropics. Journal of Tropical Geography, v.39, p.24-33, 1974.

ERICKSON, C.L.; CANDLER, K.L. Raised fields and sustainable agriculture in the Lake Titicaca basin of Peru. In: BROWDER, J.O. (Ed.). Fragile lands of Latin America, strategies for sustainable development. Bolder: Westview Press, 1989. p.230-248.

HIJMANS, R.J.; CONDORI, B.; CARRILLO, R.; KROPFF, M.J. A quantitative and constraint-specific method to assess the potential impact of new agricultural technology: the case of frost resistant potato for the Altiplano (Peru and Bolivia). Agricultural Systems, v.76, p.895-911, 2003.

JANUSEK, J.W. Tiwanaku and its precursors: Recent research and emerging perspectives. Journal of Archaeological Research, v.12, p.121-183, 2004.

KOLATA, A.L. The technology of agricultural production in the Tiwanaku State. Latin American Antiquity, v.22, p.99-125, 1991.

LENNON, T.J. Raised fields of Lake Titicaca, Peru: A preHispanic water management system. Boulder: University of Colorado, 1982. (Ph.D. - Thesis).

LHOMME, J.P.; VACHER, J.J. Modelling nocturnal heat dynamics and frost mitigation in Andean raised field systems. Agricultural and Forest Meteorology, v.112, p.179-193, 2002.

MUNDY, C.; CREAMER, N.G.; CROZIER, C.R.; WILSON, L.G. Potato production on wide beds: Impact on held and selected soil physical characteristics. American Journal of Potato Research, v.76, p.323-330, 1999.

ORTLOFF, C.R.; KOLATA, A.L. Hydraulic analysis of Tiwanaku aqueduct structures at Lukurmata and Pajchiri, Bolivia. Journal of Archaeological Science, v.16, p.513-535, 1989.

ROCHE, M.A.; BOURGES, J.; CORTES, J.; MATTOS, R. Climatologia e hidrologia de la cuenca del lago Titicaca. In: DEJOUX, C.; ILTIS, A. (Ed.). EI Lago Titicaca, sintesis del conocimiento limnologico actual. La Paz, Bolivia: ORSTOM; HISBOL, 1991. p.83-104.

SANCHEZ DE LOZADA, D.; BAVEYE, P.; RIHA, S. Heat and moisture dynamics in raised fields of the Lake Titicaca region (Bolivia). Agricultural and Forest Meteorology, v.92, p.251265, 1998.

STACHE, A. Konventionelle Landnutzung und traditionelle Hochbeete (Suka Kollus) am Titicacasee. Bolivien: Agrarokologische Standortbedingungen im Vergleich. Cottingen: Georg-August-Universitat, 2000. (Ph.D. - Dissertation).

XUAN, V-T.; QUANG, N.K.; TRI, L.Q. Rice cultivation on acid sulphate soils in the Vietnamese Mekong delta. In: BANGKOK SYMPOSIUM ON ACID SULPHATE SOILS; INTERNATIONAL SYMPOSIUM ON ACID SULPHATE SOILS, 2., Bangkok, Thailand, 1981. Proceedings. Wageningen: ILRI, 1982. p.251-259.

$\overline{\text { Received August }}$ 16, 2005

Accepted July 06, 2006 